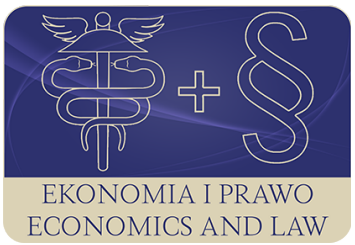

EKONOMIA I PRAWO. ECONOMICS AND LAW

Volume 17, Issue 2, June 2018

p-ISSN 1898-2255, e-ISSN 2392-1625

www.economicsandlaw.pl

EKONOMIA I PRAWO
ECONOMICS AND LAW

ORIGINAL ARTICLE

received 13.06.2017; revised 25.03.2018; accepted 30.06.2018

Citation: Kotliński, K. (2018). The economic consequences of leaving European Union by Great

Britain. Ekonomia i Prawo. Ecomomics and Law, 17(2): 157-167.

doi:10.12775/EiP.2018.011.

\title{
The economic consequences of leaving European Union by Great Britain
}

\author{
KAMIL KOTLIŃSKI \\ University of Warmia nad Mazury in Olsztyn, Faculty of Economics, Department \\ of Macroeconomics, ul. M. Oczapowskiego 4, 10-719 Olsztyn, Poland \\ घk.kotlinski@uwm.edu.pl
}

\begin{abstract}
Motivation: In a referendum on June 23, 2016, the British people voted to leave the European Union. No nation state has ever left the EU. The theory and practice of European integration is rich, but scientific studies considering the opposite situation thus far do not exist. So the question of economic consequences caused by Great Britain leaving the European Union is very pertinent.

Aim: The aim of this article is to identify and discuss the direct economic consequences of Great Britain leaving the European Union. The analysis was performed for the United Kingdom and for the European Union. Poland is a part of the EU. Therefore, among the effects on the EU side of the research there is an emphasis on the results for Poland.

The effect of budgets, trade and migration has been analyzed.

Results: The effects of the United Kingdom leaving the EU will be more unfavorable for the UK than for the EU. The amount of losses depends on the type of Brexit. A soft Brexit means a relatively slow negotiation designed to retain as close as possible a relationship with the rest of the EU. Access to the EU's single market will reduce losses due to having as few tariffs as possible. A hard Brexit would mean getting out of the EU quickly, having no institutional or political relationship with the union, and regaining full control of UK borders. Therefore, a negotiated free trade deal with the EU would seem to reduce losses

for everyone.
\end{abstract}

Keywords: integration; disintegration; Brexit

JEL: F02; F15; F36 


\section{Introduction}

In a referendum on the $23^{\text {rd }}$ of June 2016, the British people voted to leave the European Union. On the $2^{\text {th }}$ of March 2017, the United Kingdom notified the European Council of its intention to leave the European Union. Brexit will be a far-reaching event. It is an unprecedented process, since no nation state has ever left the EU. While the process of economic integration is quite well researched, the theory of disintegration does not actually exist.

It is pertinent to ask about the economic consequences of the British withdrawal from the European Union. The aim of this article is to identify and discuss the direct economic consequences of Great Britain leaving the European Union. The analysis explores the economic effects for the United Kingdom and for the European Union. Poland is a part of the EU, so among the results for the EU the research puts emphasis on the effects for Poland.

Brexit will lead to a reduction in economic integration between the United Kingdom and the remaining EU-27 states (Sampson 2017, s. 169). According to the theory of economic integration, the European Union is a single market with free movement of goods, services, capital and labour. The European Union has its own budget, and the United Kingdom has a significant share of it. Therefore, the scope of this research is the economic effects of Brexit on the common budget, trade, migration and GDP. In this paper, investments are not examined. Only the direct economic consequences are analysed, this research also leaves out political and social consequences.

The time range of analysis focuses on the medium run effects after Brexit occurs. This study is not concerned with economic uncertainties, which are the effects that will impact the economies of the United Kingdom and/or the European Union in advance of Brexit.

An attempt to give an explanation of the economic consequences for Poland is an element of novelty in this research.

\section{Literature review}

\subsection{The legal basis of leaving the European Union}

The Treaty of the European Union introduced a provision (Art. 50 sec. 1) providing for the right of each Member State to withdraw from the EU in accordance with its constitutional requirements. It also regulates the mode of departure (sec. 2-4), which is the quasi-inverse of the accession process. According to these regulations, the procedure commences with the notification of the intent to withdraw by a Member State to the European Council. The European Council then provides guidelines for the EU negotiations with that State, 'setting out the arrangements for its withdrawal, taking into account the framework for its future relationship with the Union'. The agreement regulating all issues 
related to withdrawal is concluded on behalf of the Union by the EU Council, after obtaining the consent of the European Parliament. The actual date of leaving the EU is from the date of entry into force of the withdrawal agreement or, if that was not possible, 2 years after the notification, or later if the European Council, in agreement with the Member State, unanimously decides to extend this period. The withdrawing Member State does not participate in the EU decision-making process (Kuźnar \& Menkes, 2017, p. 439).

Negotiations between the United Kingdom and the European Union officially started a year after the referendum, on the 19th of June, 2017. The first phase of negotiations under Article 50 TEU on the United Kingdom's orderly withdrawal from the European Union has been provided the same arrangements. The arrangements regarding free movement on the Northern Irish border are to protect the rights of Union citizens in the UK and UK citizens in the Union. However, the negotiators have written: 'Under the caveat that nothing is agreed until everything is agreed, the joint commitments set out in this joint report shall be reflected in the Withdrawal Agreement in full detail. This does not prejudge any adaptations that might be appropriate in case transitional arrangements were to be agreed in the second phase of the negotiations, and is without prejudice to discussions on the framework of the future relationship.' (European Commission, 2017, p. 1). The second phase of negotiation has not begun, at the time of writing this article (January 2018).

Unlike the accession of new Member States to the EU, the withdrawal of a Member State does not require ratification by the remaining Member States. However, any treaty changes or international agreements (such as a free trade agreement) that might be necessary as a consequence of the withdrawal agreement would need to be ratified by the remaining Member States.

Great Britain would be carving out an unprecedented path. No nation state has ever held a referendum and then left the EU. However, there is part of one country that has gone through the process of exiting the EU - Greenland, one of Denmark's overseas territories. It staged a referendum in 1982 after gaining a high degree of self-government from Denmark.

Greenlanders voted to leave the EU. There followed a series of difficult and protracted negotiations between Greenland and the Danish government, as well as between the Danish government and the European Commission, particularly with regard to fisheries. It finally left the EU in 1985.

In the case of Great Britain, the economy is many times larger and more complex. In addition, the level of EU integration is much deeper, so the responsibilities and connections have ballooned over the past 30 years. That is why the Greenland precedent is completely incomparable with the current situation.

\subsection{Disintegration and potential trade barriers}

Trade liberalization tends to increase welfare due to an expansion in the set of feasible allocations that leads to Pareto superior outcomes. This superiority 
translates into the availability of cheaper consumption goods and/or inputs (Eaton \& Kortum, 2002, pp. 1741-1779). Further benefits are an increase in the number of varieties available for consumption (Krugman, 1980, pp. 950-959) and productivity increases due to growth in competition from abroad (Melitz, 2003). In long-term analysis, the gains from trade can be considerably larger due to dynamic effects. Trade openness can increase growth rates due to a rise in investment (Wacziarg, 2001), increases in technology diffusion (Sampson, 2013; Wacziarg, 2001), export learning effects (Albornoz et al., 2012, pp. 17-31; Egger et al., 2011, pp. 113-143) and greater investment in R\&D (Bloom et al., 2016). So leaving a trade block like the European Union generates no benefits but causes consequent losses.

Today the European Union is a political and economic union, including a Single Market with the free movement of goods, services, people and capital. Within the European Single Market, trade is not only without tariffs, but is also free of non-tariff barriers. Non-tariff barriers include a wide range of measures that raise the costs of trade such as border controls, rules of origin checks, cross-country differences in regulations over things like product standards and safety, and threats of anti-dumping. Holmes et al. (2016, p. 25) called it a 'regulatory union', which means that all members incorporate EU mandatory standards into their legislation, along with the rules for establishing conformity with the rules. Hence products produced within the EU can be assumed to conform to mandatory standards and can circulate without further inspection to any other part of the EU. A British exit from the EU would lower trade between the UK and the EU because of higher tariff and non-tariff barriers to trade. In addition, the UK would benefit less from future market integration within the EU (Dhingra et al., 2016, p. 4).

It is very difficult to measure the effect of non-tariff barriers on trade volumes, but they are generally held to be high. The costs of administering the rules of origin will reduce trade - in some estimates by up to 9 per cent (Cadestin et al., 2016) - and differences in standards and the additional burden of certification is bound to increase this. It is not that trade will cease, but that the extra cost will discourage some trade and cut the returns to that which remains. The costs of the bureaucracy must be paid for at some point, and this will reduce profits and wages, or increase consumer prices.

\section{Methods}

A critical analysis of existing literature is used. Both theoretical papers as well as empirical ones has been reviewing.

Since Great Britain is still a member of the EU, we do not have empirical economic data for after the British leave the EU. Therefore, the long-term effects of withdrawing from the EU can currently only be estimated. A future agreement between the UK and EU-27 is still unknown, and the economic consequences of Brexit depend on it. The impact of leaving the Single Market 
on trade barriers would depend upon what, if any, new deal the United Kingdom and the European Union negotiate. Two extreme scenarios are analysed: a 'hard' Brexit and a 'soft' Brexit.

A 'hard Brexit' entails trading with the EU-27 purely on WTO terms and not bothering to even try negotiating special arrangements (Holmes et al., 2016, p. 26). A 'Hard Brexit' would put Great Britain in a position more like third countries. That means that they are also not part of the single market, which makes their exports into it subject to both tariffs and non-tariff barriers. In this extreme scenario, the UK is not subject to the free movement of people from other EU countries or to any of the EU's single-market regulations. Moreover, they would not make any payments into the EU budget.

A Soft Brexit means that the United Kingdom exits the EU, but receives a status similar to that of Norway or Switzerland, which are outside the EU but largely inside the single market. Norway and Switzerland also pay into the EU budget. In the latter situation, those countries become part of the EU 'regulatory union'. They must adopt all EU legislation in the covered sectors (all goods and services except agriculture and fisheries), including free movement of internal labour (with no restrictions), but in return get access to the entire Single Market free of all technical barriers. The 'regulatory union' also implies, however, that individual members cannot sign agreements with third-party countries that affect technical regulations (Holmes et al., 2016, p. 25).

\section{Results}

\subsection{The budgetary implications for Great Britain and European Union}

A cutting of the UK's payments to the EU budget was one of the main arguments for leaving. The United Kingdom is one of the biggest net contributors to the EU budget. The net contribution is the difference between the total expenditure from the EU budget in the UK and the UK contribution to the EU's own resources, taking into account the UK rebate which, broadly, reduces by 66 per cent the net contribution which the UK would otherwise have made. The net contribution has varied from year to year from $0.23 \%$ GNI to $0.48 \%$ GNI (Matthews, 2016, p. 18).

Total EU spending in the UK was worth 7 billion euros in 2016. This represents an equivalent of $0.3 \%$ of GNI for this country. The total UK contribution to the EU budget was worth 13.460 billion euro in 2016. It is relatively small, and is only $0.7 \%$ of GNI. By comparison, for Poland this ratio is $0.9 \%$ of GNI, and for Germany it is $0.73 \%$ of GNI (European Commission, 2018). Taking into account only the net contribution of the UK, under the 'hard' Brexit scenario Great Britain leaving the EU would yield a potential fiscal saving of $0.4 \%$ of the GDP at most. 
The UK will remain a member of the EU until its departure has been negotiated and will continue to contribute to the EU budget until it formally leaves. The UK and the EU have reached an agreement in principle on a financial settlement for the UK's withdrawal. The approach agreed upon for calculating the settlement is based on the principles that: the UK pays for its share of the commitments taken on during its EU Membership, no remaining Member State is made financially worse off by the UK's withdrawal, and the UK should neither pay more nor earlier than if it had remained a Member State (Keep, 2018). Great Britain's potential obligations are concentrated in three areas: legally binding budget commitments of the current Multi-annual Financial Framework period (2014-2020); pension promises to EU officials; and contingent liabilities - such as bailout loans to Ireland - that would only require payment in certain circumstances (Barker, 2017).

Brexit will affect the future Multi-annual Financial Framework. The EUbudget must always be balanced and the British net contribution is about 7\% of the EU-budget. There are two possibilities to reduce this significant gap. Net payers like Austria are in favor of reducing the budget. Net beneficiaries, like Poland, are opposed to reducing budget expenditures. With the UK no longer making a net contribution, a balance must be found through increased contributions from all other members. Additional gross contributions after Brexit may grow 7.0-8.5\% for every remaining EU Member State (Aichele \& Felbermayr, 2015, p. 33). Poland would need to pay more than 400 million euros (Kotliński, in press), about $0.1 \%$ GNI. So for countries like Poland, the net benefits will be lower.

However, whether the UK will no longer pay contributions after Brexit is questionable. In the case of a soft Brexit, a model similar to that used for Norway and Switzerland could be conceivable. These countries contribute to the EU budget in return for gaining access to the EU single market. On a per capita basis, Norway's financial contribution to the EU is $83 \%$ as large as the UK's payment. If the United Kingdom were to pay per capita contributions equivalent to those of Switzerland, its payments would be reduced by around 60\% (House of Commons, 2013, p. 23). The UK Government says that it may pay to participate in some EU programmes after Brexit. For instance, the UK might pay to remain in Horizon 2020, the EU's research and innovation programme. Exit negotiations will determine the extent of the UK's future participation in EU programmes and any cost (Keep, 2018). In the case of a 'soft' Brexit, the UK would contribute to the EU-budget, but less than they do today. It would be less painful for the remaining states than a 'hard' Brexit without any British payments.

\subsection{Potential reduction in trade between Great Britain and EU}

The hard Brexit scenario assumes United Kingdom trade with the EU-27 will be purely on WTO terms. The most favored nation principle (MFN) is an an- 
tidiscrimination principle from the WTO stating that trade advantages that are conceded to one country must also be conceded to all others. Regional free trade agreements are exempted from the MFN principle. The most favored MFN customs duties that the EU would hypothetically levy against the United Kingdom would total around $4 \%$. The EU's external tariffs are especially high for the vehicle and automotive component segment (up to 10\%), and are not insignificant for machines either. The United Kingdom's exit from the EU could result in substantial tariff increases in these sectors for imports from the UK. In other areas such as minerals or electrical technology, levies zero MFN tariffs for the most part. Consequently, exiting the EU could have a strong heterogeneous effect on the UK's economic sectors (Aichele \& Felbermayr, 2015, p. 20).

According Aichele and Felbermayr (2015, pp. 38-39), estimation of the loss of all free trade agreements including full withdrawal from the EU would cost the United Kingdom between 1.6 and 3\% of its real income. Ottaviano et al. (2014) calculated the changes in welfare, measured by real consumption, generated by a UK exit from the EU. They found that bilateral increases of tariffs and non-tariff barriers between the UK and EU generally lead to a drop in UK welfare even after accounting for lower fiscal transfers to the EU. They also found that the UK has even more to lose in a scenario where non-tariff trade costs within EU countries continue to fall more over time than in other OECD countries, something that seems likely to occur. A static welfare fall of 3.62\% is a pessimistic scenario. Discounting the fiscal benefits implies a total British welfare fall of 3.09\% (Ottaviano et al., 2014). Dhingra et al. (2016) estimated the effect of Brexit on the UK's trade and living standards, by using a modern quantitative trade model of the global economy. In the 'hard' Brexit scenario, British welfare is reduced by $2.92 \%$ due only to trade effects.

In a 'soft' Brexit scenario, losses are lower. Ottaviano et al. (2014, p. 8) calculated the UK will lose a total of $1.13 \%$ of its GDP in the most optimistic scenario. Aichele \& Felbermayr (2015, pp. 37-39) argue that in a 'soft exit' scenario, Great Britain will lose approximately $0.6 \%$ of its real income in the static model of general equilibrium. In Dhingra's et al. $(2016$, s. 5) optimistic scenario, there is an overall fall in income of $1.28 \%$ that is largely driven by current and future changes in non-tariff barriers.

Results from the academic literature show that by reducing trade, Brexit will lower UK living standards. The fall in trade affects other countries as well. Since $45 \%$ of UK exports go to the EU, while an average of $6.7 \%$ of EU exports go to the UK, the costs of reducing trade will be much lower for the remaining EUstates than for Great Britain. Altogether the EU would lose between -0.12\% and $-0.29 \%$ of its GDP (Dhingra et al., 2016, pp. 5-6). Aichele \& Felbermayr (2015, pp. 38-40) based on a static model of general equilibrium estimated the losses for different Brexit scenarios. The average GDP losses for the EU would be $-0.10 \%$ in the case of a 'soft' Brexit and $-0.36 \%$ in the case of a 'hard' Brexit. The countries that will lose the most are those currently trading the most with the UK. Ireland will suffer the largest proportional losses. 
For Poland, Great Britain is an important, but not the most important, trading partner. $6.8 \%$ of total Polish exports go to the UK ( $2^{\text {nd }}$ partner) and $2.6 \%$ of Polish imports come from the UK ( $9^{\text {th }}$ place) (Global Edge, 2017). In a 'soft' Brexit scenario, Poland will lose $0.07 \%$ of its real income, and $0.24 \%$ under a 'hard' Brexit scenario (Aichele \& Felbermayr, 2015, pp. 38-40).

A hard Brexit would entail higher costs for trade, due to non-tariff barriers and most likely tariffs. The fall in trade will reduce living standards more in the UK than in the remaining states of the EU-27. Results found in the academic literature show that under a 'hard' Brexit scenario, losses in welfare will be higher for everyone than under a 'soft' Brexit scenario.

\subsection{Consequences of potential changes in migration policy}

One of the factors that affected people's decisions about Brexit at the ballot box was immigration (Katwala et al., 2016, pp. 3-14). The decision to leave the EU aroused great uncertainty about the rights and obligations of EU citizens in the UK and UK citizens in the EU. Leaving the EU will have a major impact on immigration policy. In the United Kingdom, there are 8.7 million immigrants, including 3.55 million nationals from other EU countries. Of these, 47\% were from the 'old EU' (countries that were members of the EU prior to its expansion in 2004). Over half were from the 'new EU'. $42 \%$ were from the eight eastern European countries that joined the EU in 2004 (EU-8), 10\% were from Bulgaria and Romania and less than $1 \%$ were from other EU states (Katwala et al., 2016, p. 15; The Migration Observatory, 2017). Poles are the largest group, accounting for $15.7 \%$ of foreign citizens.

For Poland, Romania and other eastern European countries, it is important to protect EU citizens, who live and work in the UK. A very pessimistic vision is the repatriation of all EU citizens from the UK, but this is an extremely exaggerated fear. Barriers against new immigrants are almost certain, but there is no expected change in the status of EU citizens already lawfully residing in the UK.

Much will depend on the situation in the British labour market after Brexit. If the unemployment rate rises (which is highly probable after leaving the EU), some restrictions towards new immigrants will be implemented. However, the expectation that most migrants will return home are unrealistic. The EU nationals who have lived continually and lawfully in the UK for at least five years can apply for permanent residence status. This immigration status gives them the same rights as non-EU nationals and enables them to apply for British citizenship after one year. Labour Force Survey data suggests that an estimated 62\% of EU nationals in the UK have been there for more than five years and hence already qualify for permanent residency (The Migration Observatory, 2017). The rest of them can immigrate to other countries of the European Economic Area. The return of even a quarter of emigrants would not be a catastrophe for Poland, because the labour market condition today is much better than it was 
in 2004 (the year of EU accession). Repatriates with foreign skills, international experience and contacts would have a positive impact on the Polish economy.

According to economic theory, contrary to popular belief, ceasing migration flows between the UK and other EU countries will also tend to decrease welfare not only in the source region but also in the destination region (di Giovanni et al., 2012). The main conclusions from Armstrong's \& van de Ven's (2016) research are that reductions in immigration would have a negative impact on public finances. To offset these impacts, a policy change in the form of increases in national insurance contributions, reductions in pensioner benefits, or increases in the state pension age could be used. More restrictive immigration policies would have more negative impacts. Brexit will hurt entrepreneurship in the UK due to, among other things, the well-established connection between immigration and entrepreneurship, if there are post-Brexit barriers to immigration (Cumming \& Zahra, 2016, p. 690). Felbermayr et al. (2010, pp. 177-179) utilize econometric methods to estimate the effect of a change in immigrant numbers on the per capita income of the host country. Depending on the econometric model, a 10\% reduction in immigration from the EU would reduce the UK's income per capita by between 0.5 and $1.1 \%$. If a higher percentage of European immigrants leave the United Kingdom, the losses could grow significantly. A $50 \%$ reduction in immigration would reduce the UK's per capita long-term income by between 2.7 and $6.2 \%$. Furthermore, although the presented estimates should be treated with caution, they all point out perceptible negative effects for the United Kingdom.

\section{Conclusion}

The economic consequences of Great Britain leaving the EU depend on various factors, especially the results of political negotiation.

Great Britain leaving the EU would yield a potential fiscal savings of $0.4 \%$ of GDP for Great Britain at most under a 'hard' scenario. In the case of a 'soft' Brexit, the UK would contribute to the EU-budget, but less than they do today. For the remaining EU states, the cutting of British payments means an increase in their own gross contributions.

In each scenario, the UK losses due to trade effects are higher than the potential fiscal benefits. Different estimations give similar results. In the case of a soft Brexit, the UK's welfare will be reduced by $0.60-1.28 \%$ due to trade effects. In the case of a hard Brexit, costs will be higher (by about 3\% according to static analysis). From a macroeconomic point of view, if the UK restricts migration, the British economy will be the biggest loser as a consequence.

The economic costs of Brexit will be substantial for the United Kingdom, and reorganizing all the country's foreign economic relationships entails a high degree of difficult risk prediction. Moreover, other EU members will suffer from a Brexit, especially Ireland. Poland will suffer as well, but not as much. A 'soft' Brexit would generate fewer losses for the United Kingdom and all the re- 
maining EU-27 States. Future research is clearly warranted in the areas of investment and indirect consequences.

\section{References}

Aichele, R., \& Felbermayr, G. (2015). Cost and benefits of a United Kingdom exit from the European Union. Retrieved 04.02.2018 from https://www.bertelsmann-stiftung.de.

Albornoz, F., Calvo Pardo, H.,F., Corcos, G., \& Ornelas, E. (2012). Sequential exporting. Journal of International Economics, 88(1). doi:10.1016/j. jinteco.2012.02.007.

Armstrong, A., \& van de Ven, J. (2016). The impact of possible migration scenarios after 'Brexit' on the state pension system. Economies, 4(4). doi:10.3390/ economies4040023.

Barker, A. (2017). The $€ 60$ billion Brexit bill: How to disentangle Britain from the EU budget. Retrieved 04.02.2018 from http://www.cer.eu.

Bloom, N., Draca, M., van Reenen, J. (2016). Trade induced technical change? The impact of Chinese imports on innovation, it and productivity. The Review Economic Studies, 83(1). doi:10.1093/restud/rdv039.

Cadestin, C., Gourdon, J., \& Kowalski, P. (2016). Participation in Global Value Chains in Latin America: Implications for Trade and Trade Related Policy. OECD Trade Policy Papers, 179. doi:10.1787/5jlpq80ts8f2-en.

Cumming, D., \& Zahra, S. (2016). International business and entrepreneurship implications of Brexit. British Journal of Management, 27(4). doi:10.1111/1467-8551.12192.

Dhingra, S., Ottaviano, G., Sampson, T., \& Van Reenen, J. (2016). The consequences of Brexit for UK trade and living standards. Retrieved 04.02.2018 from http://cep.lse.ac.uk.

di Giovanni, J., Levchenko, A., \& Ortega, F. (2012). A global view of cross-border migration. Journal of the European Economic Association, 13(1). doi:10.1111/ jeea.12110.

Eaton, J., \& Kortum, S. (2002). Technology, geography, and trade. Econometrica, 70(5). doi:10.1111/1468-0262.00352.

Egger, P., Larch, M., Staub, K.E., \& Winkelmann, R. (2011). The trade effects of endogenous preferential trade agreements. American Economic Journal: Economic Policy, 3(3). doi:10.1257/pol.3.3.113.

European Commission. (2017). Joint report from the negotiators of the European Union and the United Kingdom Government on progress during phase 1 of negotiations under Article 50 TEU on the United Kingdom's orderly withdrawal from the European Union. Retrieved 05.02.2018 from https://ec.europa.eu.

European Commission. (2018). Budgets and funding. How much does the UK contribute and receive? Retrieved 04.02.2018 from http://europa.eu.

Felbermayr, G., Hiller, S., \& Sala, D. (2010). Does immigration boost per capita income? Economics Letters, 107(2). doi:10.1016/j.econlet.2010.01.017. 
Global Edge. (2017). Trade Statistics. Retrieved 29.03.2017 from https:// globaledge.msu.edu.

Holmes, P., Rollo, J., \& Winters, A. (2016). Negotiating the UK's postBrexit trade arrangements. National Institute Economic Review, 238(10). doi:10.1177/002795011623800112.

House of Commons. (2013). Leaving the EU. House of Commons Research Paper, $13 / 42$.

Katwala, S., Rutter, J. \& Ballinger, S. (2016). What next after Brexit? Immigration and integration in post-referendum Britain. Retrieved 29.03.2017 from http:// www.britishfuture.org.

Keep, M. (2018). The UK's contribution to the EU budget. House of Commons Briefing Paper, 7886.

Kotliński, K. (in press). Skutki Brexitu dla budżetu Unii Europejskiej. Prace Naukowe Uniwersytetu Ekonomicznego we Wroctawiu.

Krugman, P. (1980). Scale economies, product differentiation, and the pattern of trade. American Economic Review, 70(5).

Kuźnar, A., \& Menkes, J. (2017). Will Brexit cause the whole Britain to leave the European Union? Ekonomia i Prawo. Economics and Law, 16(4). doi:10.12775/EiP.2017.030.

Matthews, A. (2016). The potential implications of a Brexit for future EU agrifood policies. EuroChoices, 15(2). doi:10.1111/1746-692X.12128.

Melitz, M. (2003). The impact of trade on intra-industry reallocations and aggregate industry productivity. Econometrica, 7l(6). doi:10.1111/1468-0262.00467.

Ottaviano, G., Pessoa, J.P., Sampson, T., \& Van Reenen, J. (2014). The costs and benefits of leaving the EU. CFS Working Paper Series, 472. doi:10.2139/ ssrn. 2506664.

Sampson, T. (2013). Dynamic selection and the new gains from trade with heterogeneous firms. FIW Working Paper, 122.

Sampson, T. (2017). Brexit: the economics of international disintegration. Journal of Economic Perspectives, 31(4). doi:10.1257/jep.31.4.163.

The Migration Observatory. (2017). Migrants in the UK: an overview. Retrieved 29.03.2017 from http://www.migrationobservatory.ox.ac.uk.

Wacziarg, R. (2001). Measuring the dynamic gains from trade. The World Bank Economic Review, 15(3). doi:10.1093/wber/15.3.393.

\section{Acknowledgements}

Author contributions: author has given an approval to the final version of the article.

Funding: this research was fully funded by the University of Warmia and Mazury in Olsztyn, Faculty of Economics, Department of Macroeconomics statutory sources.

Note: the results of this study were presented at 9th International Conference on Applied Economics Contemporary Issues in Economy (June 22-23, Toruń, Poland). 
